[Agr. Biol. Chem., Vol. 35, No. 6, p. 856 861, 1971]

\title{
Streptomycin-phosphorylating Enzyme Produced by Streptomyces griseus
}

\author{
By Osamu Nimi, Gaku Ito, Yasuhiro Ohata, Shunji Funayama \\ and Ryosaku NoMI \\ Department of Fermentation Technology, Faculty of Engineering, \\ Hiroshima Lniversity \\ Received October 30, 1970
}

\begin{abstract}
Streptomycin-phosphorylating enzyme was reported previously to be produced in mycelium of Streptomyces griseus HUT 6037 at late stage of growth. In the present investigation, this enzyme was purified 200 times as high in specific activity as cell-free extract by means of salting out, chromatography on DEAE-Sephadex A-25 and gel filtration with Sephadex G-100. This enzyme was most stable at $\mathrm{pH} 8.0$ and required $10^{-2} \mathrm{M} \mathrm{Mg}^{2+}$ in the reaction mixture for the highest activity. It lost the activity by heat treatment at $40^{\circ} \mathrm{C}$ for $15 \mathrm{~min}$ in absence of the substrate.

Mutant cultures were prepared on productivity of or tolerance to streptomycin, and their capacity to produce streptomycin-phosphorylating enzyme was examined. The cultures which had low to no capacity to produce streptomycin produced a small amount to none of the enzyme, suggesting that production of the streptomycin-phosphorylating enzyme had some correlation with streptomycin productivity of the culture. But no definite correlation was observed between productivity of the enzyme and the capacity to tolerate streptomycin.
\end{abstract}

In the previous paper," a streptomycinphosphorylating enzyme was shown to be produced in the mycelium of Streptomyces griseus HUT 6037 in the stationary to autolyzing phase. This enzyme phosphorylated $\mathrm{C}_{6}-\mathrm{OH}$ of streptidine moiety of streptomycin in presence of ATP and $\mathrm{Mg}^{2+}$

In the present paper, further purification and characterization of the enzyme were carried out, and, in the various mutants from the same culture as above, the correlation was investigated between the capacity to produce the enzyme and that to produce or tolerate streptomycin.

\section{MATERIALS AND METHODS}

The same materials and methods as those in the pre-

1) O. Nimi, G. Ito, S. Sueda and R. Nomi, Agr. Biol. Chem., 35, 848 (1971). vious paperll were employed in the present investigation in respect to strain, inoculum, culture medium, preparation of cell-free extract, assay of antibiotic potency and estimation of phosphorylated streptomycin.

Estimation of streptomycin-phosphorylating activity in enzyme preparation. The reaction mixture for phosphorylation of streptomycin consisted of $0.4 \mathrm{ml}$ of 5 $\mathrm{mM}$ streptomycin sulfate, $0.4 \mathrm{ml}$ of $15 \mathrm{mM}$ ATP (disodium salt), $0.2 \mathrm{ml}$ of $0.1 \mathrm{M}$ magnesium sulfate, 0.2 $\mathrm{ml}$ of $1 \mathrm{M}$ Tris-maleate buffer ( $\mathrm{pH} 7.0$ ), $0.8 \mathrm{ml}$ of enzyme solution and a few drops of toluene. It was incubated at $30^{\circ} \mathrm{C}$ for $1 \mathrm{hr}$. For control, a reaction mixture was prepared substituting $0.5 \%$ aqueous sodium chloride solution for enzyme. As the phosphorylated streptomycin is biologically inactive, the quantity produced by the enzyme was shown with the difference of residual streptomycin in the above two reaction mixtures after incubation. The enzyme activity was expressed with the amount of streptomycin which was phosphorylated at $30^{\circ} \mathrm{C}$ for one hr 
by $1 \mathrm{ml}$ of enzyme solution in the reaction mixture.

Estimation of protein. Protein was estimated by the procedure described by Lowry et al. ${ }^{2}$ and expressed as albumin.

Dry weight of mycelium. Two $\mathrm{ml}$ of mycelium suspension or sonicated mycelium was dried in small dish made of aluminum foil at $60^{\circ} \mathrm{C}$ for $24 \mathrm{hr}$ After cooling in a desicator, it was weighed.

Preparation of streptomycin-resistant mutants. Resistant cultures were obtained from Streptomyces griseus HUT 6037 by serial transfer on Bennett agar slants which were enriched with streptomycin in gradually increased amount in each transfer.

\section{RESULTS}

\section{Partial purification of enzyme}

If the streptomycin-phosphorylating enzyme is localized near the surface of the mycelium, namely external to the protoplasmic membrane, it could be liberated from the myceli- um by osmotic shock method described by Nossal et al., ${ }^{3}$ giving an advantageous material for enzyme purification. But this was not the case when the same method was applied to 72 and $96 \mathrm{hr}$ mycelia of Streptomyces griseus HUT 6037.

When ammonium sulfate was added giving 0.6 saturation to the cell-free extract of the organism grown for $96 \mathrm{hr}$, about $90 \%$ enzyme activity in the cell-free extract was salted out. The precipitate was dialyzed against $0.03 \mathrm{M}$ Tris-HCl buffer ( $\mathrm{pH} \mathrm{8.0)}$ for $15 \mathrm{hr}$. The dialyzate was added onto a column of DEAESephadex A-25 equilibrated with the same buffer. After washing with the buffer, the column was eluted in gradient way with 0 to $5 \% \mathrm{NaCl}$ dissolved in the buffer (Fig. 1). The enzyme was eluted in about $2 \% \mathrm{NaCl}$ fractions. Those fractions were pooled and concentrated by freeze-drying. It was then subjected to gel filtration through a column of Sephadex G-100, eluting with the same buffer as above (Fig. 2). In Table I, purity

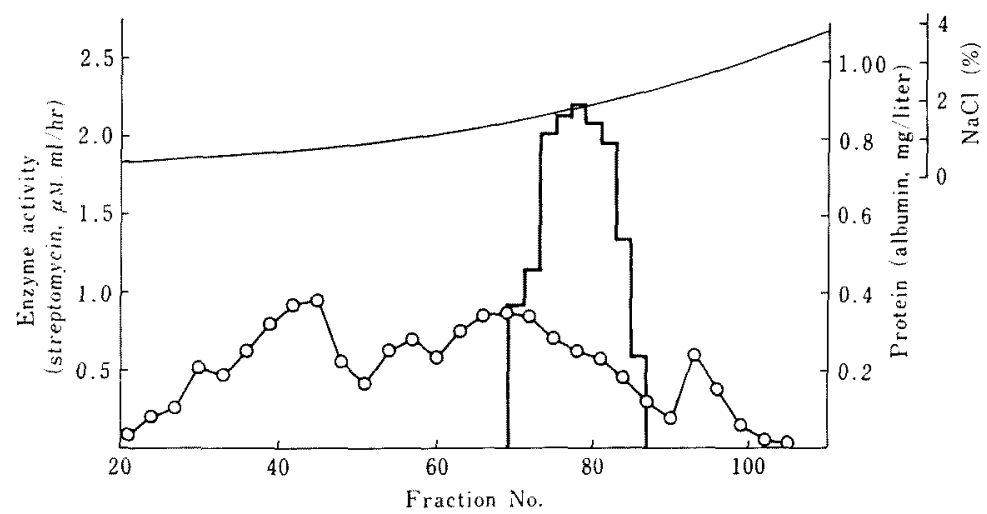

FIG. 1. Column Chromatogrophy of Streptomycin-phosphorylating Enzyme on DEAE-Sephadex A-25.

Column size: $3 \times 30 \mathrm{~cm}$. Eluting solution: 0 to $5 \%$ sodium chloride solution in $0.03 \mathrm{M}$ Tris-HCl buffer $(\mathrm{pH} 8.0)$. Fraction: $15 \mathrm{ml}$. Enzyme activity. O-O: Protein. - Concentration of sodium chloride.

Enzyme activity was expressed with the amount of streptomycin $(\mu \mathrm{M})$ which was phosphorylated by one $\mathrm{ml}$ of the fraction for one hr at $30^{\circ} \mathrm{C}$.

2) O. H. Lowry, N. J. Rosenbraugh, A.L. Farr and R. T. Rondall, J. Biol. Chem., 193, 265 (1951).
3) N. G. Nossal and L. A. Heppel, J. Biol. Chem., 241, 3055 (1966). 


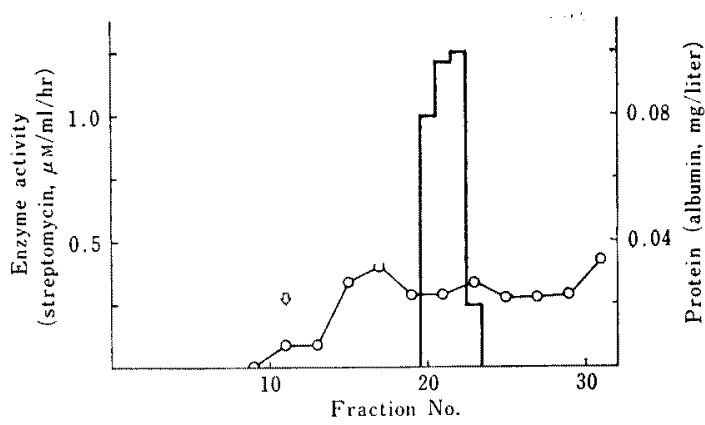

FIG. 2. Gel Filtration of Streptomycin-phosphorylating Enzyme with Sephadex G-100.

Column size: $1 \times 83 \mathrm{~cm}$. Eluting solution: 0.03 M Tris- $\mathrm{HCl}$ buffer ( $\mathrm{pH} 8.0$ ). Fraction: $3 \mathrm{ml}$. : Enzyme activity. $\mathrm{O}-\mathrm{O}$ : Protein. \&: Void volume.

Enzyme activity was expressed as in Fig. 1.

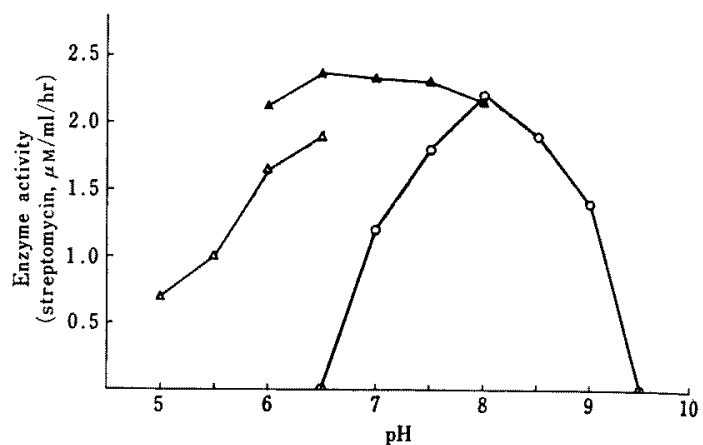

FIG. 3. Effect of $\mathrm{pH}$ on Enzyme Stability and Phosphorylating Reaction.

O-O: Effect of $\mathrm{pH}$ on enzyme stability. $\triangle-\triangle$ and $\Delta-\Delta$ : Effect of $\mathrm{pH}$ on phosphorylating reaction $(\boldsymbol{\Lambda}-\mathbf{\Lambda}, 0.1 \mathrm{M}$ Tris-maleate buffer: $\Delta-\Delta, 0.1 \mathrm{M}$ citric acid-sodium citrate buffer).

Table I. Purification and ReCovery of Streptomycin-Phosphorylating Enzyme

\begin{tabular}{lccc}
\multicolumn{1}{c}{ Enzyme preparation } & $\begin{array}{c}\text { Enzyme activity* } \\
(\mathrm{SM}: \mu \mathrm{M} / \mathrm{ml} / \mathrm{hr})\end{array}$ & $\begin{array}{c}\text { Specific activity* } \\
(\mathrm{SM}: \mu \mathrm{M} / \mathrm{mg} / \mathrm{hr})\end{array}$ & Recovery \\
\hline Cell-free extract & 2.38 & 0.42 & 100 \\
After salting out and dialysis & 2.42 & 0.86 & 88 \\
Eluate from DEAE-Sephadex A-25 & 2.0 & 14.28 & 59 \\
Eluate from Sephadex G-100 & 1.68 & 84.0 & 28 \\
SM: Streptomycin & & \\
$*$ Enzyme activity and specific activity were expressed with the amount of streptomycin \\
( $\mu \mathrm{M})$ phosphorylated by one ml of the enzyme solution and one mg protein in the enzyme \\
solution, respectively, for one hr at $30^{\circ} \mathrm{C}$.
\end{tabular}

and yield of enzyme at different stages of purification are presented. The enzyme in the eluate from Sephadex G-100 was purified 200 times as high in specific activity as the cell-free extract, giving $28 \%$ yield. This eluate was used for examination of the following enzyme properties.

\section{Influence of $p H$ on enzyme slability}

The enzyme solutions were adjusted to different $\mathrm{pH}$ values as is shown in Fig. 3 with $\mathrm{HCl}$ or $\mathrm{NaOH}$ solution and kept at room temperature for $15 \mathrm{~min}$. After readjustment of $\mathrm{pH}$ to 8.0, they were made up to a fixed volume and the phosphorylating enzyme ac- tivity was determined. The results are given in Fig. 3. This enzyme was most stable at $\mathrm{pH} 8.0$, but rapidly inactivated on either side of the $\mathrm{pH}$.

On the other hand, the influence of the substrate on stability of the enzyme was also examined at various $\mathrm{pH}$. The reaction mixtures without buffer were adjusted to different $\mathrm{pH}(5$ to 8$)$ as are shown in Fig. 3. After addition of buffer in respective $\mathrm{pH}$, the mixtures were incubated at $30^{\circ} \mathrm{C}$ for $1 \mathrm{hr}$. Citric acid-sodium citrate buffer $(0.1 \mathrm{M})$ and Trismaleate buffer $(0.1 \mathrm{M})$ were employed for $\mathrm{pH}$ 5 to 6.5 and for $\mathrm{pH} 6.5$ to 8 , respectively. As is shown in Fig. 3, the $\mathrm{pH}$ range of maxi- 
mum activity extended in comparison with that in absence of the substrate. This indicated that the enzyme was much stabilized in presence of the substrate. The effective $\mathrm{pH}$ ranged from 6 to 8 in the latter experiment and most stable $\mathrm{pH}$ was 8.0 in the former experiment. But $\mathrm{pH} 7.0$ was adopted as the reaction $\mathrm{pH}$, because phosphorylated streptomycin formed could easily be dephosphorylated at alkaline $\mathrm{pH}$ if the alkaline phosphatase (possibly $\mathrm{H}$ enzyme) contaminated the enzyme preparation.

\section{Influence of heat on enzyme activity}

The enzyme solutions which were adjusted to $\mathrm{pH} 8.0$ were kept at different temperatures for $15 \mathrm{~min}$, then rapidly cooled. The phosphorylating activity retained by the treated enzyme solution was determined by the procedure already indicated. The results are presented in Fig. 4. The enzyme was completely inactivated by the treatment at $40^{\circ} \mathrm{C}$. However, it is noticeable that, when the enzyme was incubated with the substrate at $40^{\circ} \mathrm{C}$, considerable activity was retained after $1 \mathrm{hr}$ reaction, giving $2.25 \mu \mathrm{M} / \mathrm{ml} / \mathrm{hr}$ phosphorylated streptomycin, while little activity was

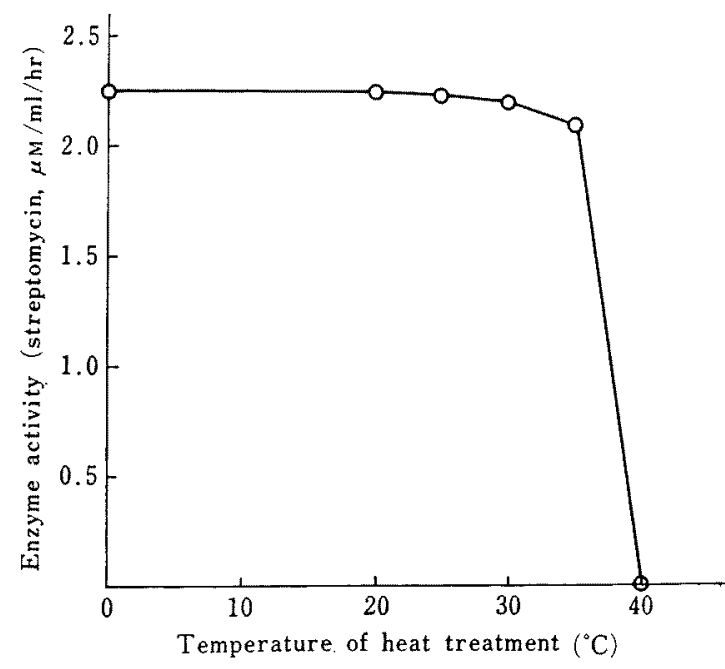

FIG. 4. Influence of Heat on Enzyme Activity. retained at $50^{\circ} \mathrm{C}$. This means that enzyme is stabilized in presence of the substrate.

\section{Influence of magnesium concentration on enzyme activity}

In order to determine the opt. concentration of $\mathrm{Mg}^{2+}$ in the reaction mixture, the influence

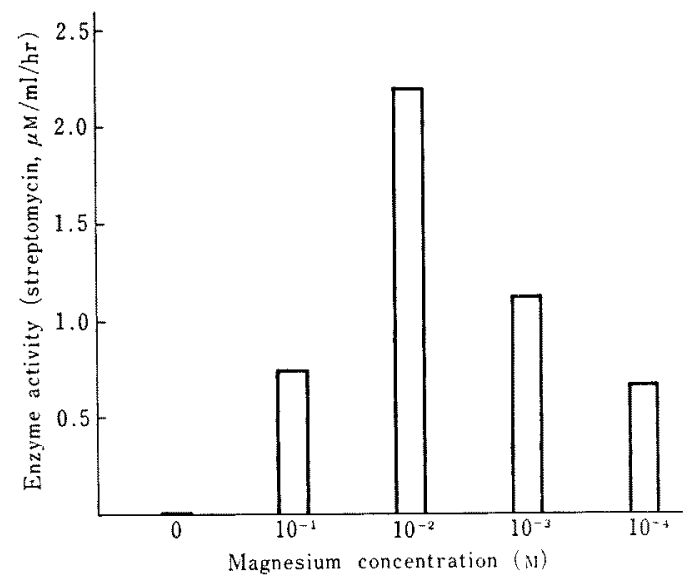

FIG. 5. Influence of Magnesium Concentration on Enzyme Activity.

TABLE II. COMPARISON IN STREPTOMYCIN-PHOSPHORylating ACTIVity of Four Cultures With DIFFERENT PRODUCTIVITY OF STREPTOMYCIN

\begin{tabular}{cccc} 
Strain & $\begin{array}{c}\text { Streptomycin } \\
\text { productivity } \\
(\mu \mathrm{g} / \mathrm{ml})\end{array}$ & $\begin{array}{c}\text { Streptomycin } \\
\text { tolerance } \\
(\mu \mathrm{g} / \mathrm{ml})\end{array}$ & $\begin{array}{c}\text { Inactivated } \\
\text { ratio }^{b 1} \\
\left(O^{6}\right)\end{array}$ \\
\hline $\begin{array}{c}\text { HUT } 6037 \\
\text { (parent) }\end{array}$ & 252 & 500 & 79 \\
$4 \mathrm{~A}-125$ & 25 & 100 & 22 \\
A-12 & trace & 200 & 0 \\
N-1 & 0 & $<50$ & 0
\end{tabular}

a) Cultures was inoculated on Bennett agar slants which contained different amount of streptomycin. The largest amount of streptomycin per $\mathrm{ml}$ in agar slant which allowed growth of the culture was described as streptomycin tolerance.

b) Inactivated ratio was expressed as a percentage ratio of phosphorylated streptomycin to substrate streptomycin after one hr reaction. Cell-free extract of $96 \mathrm{hr}$ mycelium in each strain was used as enzyme solution in the reaction mixture. 
of magnesium sulfate on the enzyme activity was examined at the concentrations of 0 , $10^{-1}, 10^{-2}, 10^{-3}$ and $10^{-4} \mathrm{M}$. The results are given in Fig. 5. The highest activity was obtained at $10^{-2} \mathrm{M}$ of $\mathrm{Mg}^{2+}$, while no activity was done in absence of the ion. Also cobaltous ion gave $80 \%$ effect of magnesium ion.

\section{Production of phosphorylating enzyme by strepto-} mycin-non-producing or low-producing cultures

In order to gain a clue to the physiological role of streptomycin-phosphorylating enzyme, the correlation was investigated between the productivity of streptomycin and that of phosphorylating enzyme. Streptomycin-nonproducing and low-producing cultures were prepared from Streptomyces griseus HUT 6037 with $\mathrm{N}$-methyl- $\mathrm{N}^{\prime}$-nitro- $\mathrm{N}$-nitrosoguanidine (Aldrich Chemical Co. Inc.). Three mutant cultures were compared with the parent one in respect of streptomycin productivity and activity of phosphorylating enzyme in $96 \mathrm{hr}$ mycelium. The results are presented in Table II. Less streptomycin-producing cultures produced less amount of phosphorylating enzyme. The streptomycin-non-producing culture gave no enzyme activity even by prolonged incubation for $20 \mathrm{hr}$.

\section{Productivity of phosphorylating enzyme in strepto- mycin-resistant cultures \\ In the above experiments, more strepto-} mycin-producing cultures produced more streptomycin-phosphorylating enzyme. Waksman et al..$^{4)}$ suggested that more streptomycinproducing culture had more tolerance to streptomycin. Three cultures which were able to grow on media containing 1000,2000 and $2500 \mu \mathrm{g}$ per $\mathrm{ml}$ of streptomycin, respectively, were prepared by serial transfers of
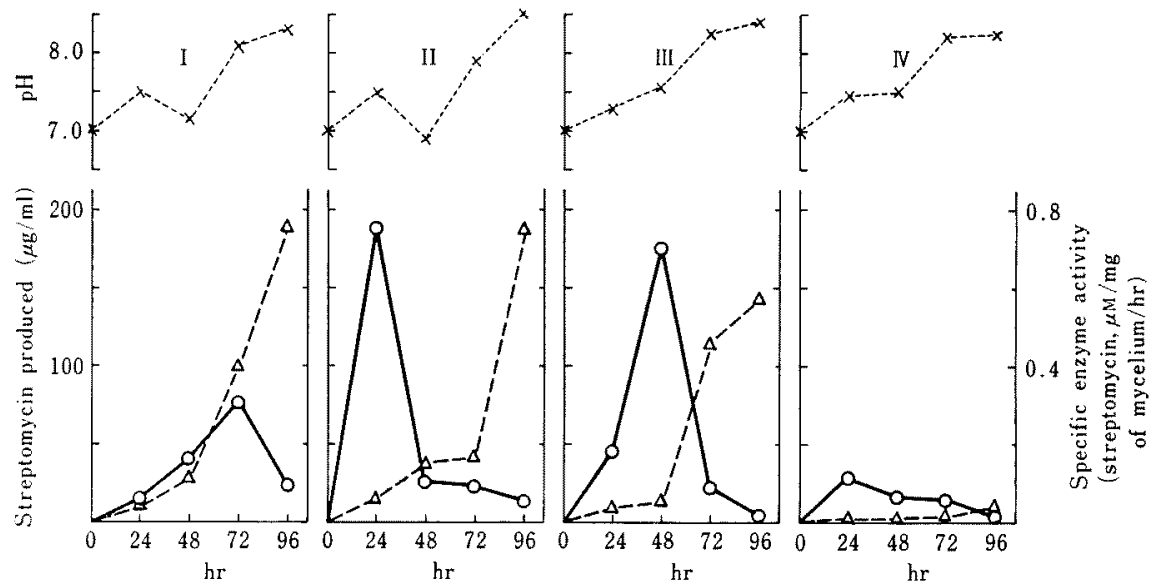

FIG. 6. Production of Streptomycin-phosphorylating Enzyme by Streptomycin-resistant Strains.

I shows the parent strain. II, III and IV show 1000,2000 and $2500 \mu \mathrm{g} / \mathrm{ml}$ streptomycin-tolerant strains, respectively. $\bigcirc-0$ : Specific enzyme activity. $\triangle-\cdots$ $\triangle$ : Streptomycin in culture broth. $x--x$ : pH.

Specific enzyme activity was expressed with the amount of streptomycin $(\mu M)$ which was phosphorylated by one $\mathrm{mg}$ of mycelium (dry weight) for one hr at $30^{\circ} \mathrm{C}$. Cell-free extract of mycelium in each hour was used as enzyme solution.

4) S. A. Waksman, H. C. Reilly and D. B. Johnstone, J. Bacteriol., 52, 393 (1946). 
the same parent culture (HUT 6037) as above on streptomycin-enriched agar slants. These resistant cultures were grown in glucose-meat extract-peptone medium and examined in each $24 \mathrm{hr}$ after inoculation on production of streptomycin and the phosphorylating enzyme. As is shown in Fig. 6, two resistant cultures produced both streptomycin-phosphorylating enzyme and streptomycin, but one did only a very small amount of the enzyme and streptomycin. It seemed likely that the productivity of the enzyme had no correlation with resistant capacity of the culture. But here again the productivity of the enzyme looked to have strong correlation to that of streptomycin, though quantitative parallelism was not always observed between the two.

It is also noticeable that, in streptomycinproducing cultures among the resistant ones, the peak of production of the enzyme preceded streptomycin excretion. This is sometimes observed also in the parent culture.

\section{DISCUSSION}

As was described above, productivity of streptomycin-phosphorylating enzyme looked to have no correlation with streptomycin tolerance of the culture, but rather to associate with streptomycin productivity. From this fact, the enzyme is supposed to play a role either in direct phosphorylation of streptomycin already produced or in phosphorylation of some intermediate on the biosynthetic pathway. Also the possibility is not excluded for the enzyme to be produced by induction with streptomycin which has been produced by the organism itself.

On direct phosphorylation of the already produced streptomycin just before excretion from mycelium, the possibility was discussed in the previous paper, denying the mechanism.

On the other hand, the authors already reported that young mycelium of Streptomyces griseus HUT 6037 which should have few streptomycin-phosphorylating enzyme excreted phosphorylated streptomycin (referred to as L) when it was suspended in aqueous glucose and sodium chloride solution. ${ }^{5 \sim 7}$ Also in streptomycin-producing culture broth, L appeared outside the cell prior to streptomycin accumulation, i.e. in young culture broth where the $\mathrm{pH}$ is below neutral. When the $\mathrm{pH}$ value of culture broth was controlled to be at slightly acid side through every stage of culture, all antibiotic accumulated in the phosphorylated form $(\mathrm{L})^{8)}$. Furthermore, few phosphorylated streptomycin are detected in free form in cell-free extract of the mycelium through all stages of growth. From these facts, it looks to be reasonable to suppose that phosphorylated streptomycin in mycelium exists in a bound form to some cell component. If the phosphorylating enzyme intrinsically participates in formation of this bound phosphorylated streptomycin, it still remains to be solved when and how the enzyme plays the role on the biosynthetic pathway.

The third possibility for induction of the enzyme formation by streptomycin is now under investigation.

5) R. Nomi, O. Nimi and T. Miyazaki, Agr. Biol. Chem., 30, 296 (1966).

6) R. Nomi, O. Nimi, T. Miyazaki, A. Matsuo and H. Kiyohara, ibid., 30, 1269 (1966).

7) idem, ibid., 31, 973 (1967).

8) R. Nomi, O. Nimi and T. Kado, ibid., 32, 1256 (1968). 